\title{
Sponge beta diversity in the Spermonde Archipelago, SW Sulawesi, Indonesia
}

\author{
Nicole J. de Voogd ${ }^{1,2, *}$, Daniel F. R. Cleary ${ }^{1,2}$, Bert W. Hoeksema ${ }^{2}$, Alfian Noor ${ }^{3}$, \\ Rob W. M. van Soest ${ }^{1}$ \\ ${ }^{1}$ Institute for Biodiversity and Ecosystem Dynamics (Zoological Museum), University of Amsterdam, PO Box 94766, 1090 GT, \\ Amsterdam, The Netherlands \\ ${ }^{2}$ National Museum of Natural History, 'Naturalis', PO Box 9517, 2300 RA Leiden, The Netherlands \\ ${ }^{3}$ Hasanuddin University, Kampus Tamalanrea, Makassar 90245, SulSel, Indonesia
}

\begin{abstract}
Sponge assemblages were investigated in the Spermonde Archipelago, southwestern Sulawesi, Indonesia. In this study spatial patterns of sponge similarity among sites were significantly related to remotely sensed environmental variables, the degree of human settlement and depth, but not to the distance between sites. Both oviparous and viviparous species groups responded to similar environmental constraints, and differences in similarity were unrelated to the distance between sites. The degree of human settlement, however, was significantly related to variation in the composition of viviparous, but not oviparous species. Our results demonstrate, most importantly, the utility of remotely sensed data in predicting the spatial turnover of diverse species assemblages such as sponges. Secondly, they show that patterns of human settlement in the Spermonde Archipelago appear to be affecting patterns of sponge beta diversity. These results highlight the need to assess and protect marine areas in biodiversity hotspots such as Indonesia.
\end{abstract}

KEY WORDS: Biodiversity $\cdot$ Indonesia $\cdot$ Porifera $\cdot$ Similarity $\cdot$ Spatial

\section{INTRODUCTION}

Indonesian coral reefs are among the most diverse in the world. No other area contributes as much to global coral reef diversity, which should make it a primary target for research, protection, and management (Mora et al. 2003). In general, diversity declines when moving away from this high-diversity region, but the heterogeneous distribution of species complicates the determination of the actual regional boundaries (Briggs 1992, 1999, 2000, Hoeksema 1990, Barber et al. 2000, Santini \& Winterbottom 2002, Hoeksema \& Putra 2003, Mora et al. 2003, Wallace et al. 2003). The diversity of Indonesia is due to both high alpha (local) and high beta (change in species composition among sites) diversity (Plotkin \& Muller-Landau 2002, Tuomisto et al. 2003). In order to preserve diversity by designing and placing conservation refugia, it is essential to understand how assemblages change in space and time (Plotkin \& Muller-Landau 2002). Despite this realization, we still know very little about how marine diversity is spatially distributed, especially among lesser-studied invertebrate taxa such as sponges (Hooper et al. 1999, Ellingsen 2002, Hooper \& Kennedy 2002).

Spatial patterns of assemblages can be due to dispersal-limiting factors or the spatial arrangement of environmental conditions. Existence of similar assemblages in adjacent habitats may be due to either or both of these conditions. Separating the contribution of space and the contribution of environment to patterns of community similarity is therefore necessary for understanding the mechanisms that influence community structure across land- and seascapes (Spencer et al. 2002). It is still unclear, however, how these factors combine to influence spatial patterns of assemblages in well-connected reef areas such as the coastal areas of the Indomalayan region. 
Recently, the availability of remotely sensed data has facilitated relating community similarity to key environmental parameters that are assumed to determine the distribution and abundance of species across large spatial scales (Turner et al. 2003). In the present study we relate the spatial variation of sponge assemblages and sponge species richness to ground-truthed, remotely sensed data sets derived from the SPOT XS satellite program, in addition to locally measured variables such as depth, water transparency, and geographic location in the Spermonde Archipelago, Indonesia. Remotely sensed habitat variables included the area of human settlement. Despite the fact that human settlement is a major source of land-use change and a threat to biodiversity, there is currently a lack of studies that explicitly address its impact (Miller \& Hobbs 2002). It is essential, however, to detect and analyze settlement patterns, in order to accurately assess the impact of humans on the environment (Henderson \& Xia 1997). However, relatively little is known about the effects of human settlement on most plants and animals (Miller \& Hobbs 2002, but see Brickle 2002).

Extensive marine biological and physical geographic studies have been carried out in the Spermonde Archipelago, which makes it one of the bestexplored regions in Indonesia (Moll 1984, Hoeksema 1990, Verheij 1993, de Voogd et al. 1999, Massin 1999, Pet-Soede 2000, Renema 2002, Cleary et al. 2005). The Indonesian Archipelago comprises $>17000$ smaller and larger islands, and, consequently, has an extended shallow-water region, which makes it the largest and most important coral reef nation in the world (Spalding et al. 2001). An important component of Indonesia's marine diversity is the wealth of species of sponges that, together with soft and stony corals, form complex reef substrates and shelter numerous other taxa such as shrimps, crabs, brittlestars, and holothurians (Kauferstein \& Mebs 1999, Massin 1999, Fransen 2002). Sponges are ancient and diverse metazoans, with complex distributional patterns, environmental requirements, and modes of reproduction. The published literature on the sponge taxonomy of Indonesia remains incomplete, although around 850 species are thought to be present (van Soest 1989, 1990, 1994, Hooper et al. 2000, de Voogd \& van Soest 2002). The unresolved taxonomy of many sponges has, however, hampered previous studies on sponge ecology, and only a limited number of studies have addressed sponge distribution, biodiversity, and related subjects (van Soest 1989, 1990, Amir 1992, de Voogd et al. 1999, 2004). An understanding of the distribution and ecology of sponges is important because sponges are sources for a wide variety of substances with bioactive properties and may continue to provide important services if managed in an ecologically sustainable manner (Munro et al. 1994, 1999, de Voogd et al. 2002).

Many environmental parameters are known to affect sponge distributions, such as depth (Wilkinson \& Cheshire 1989, Alvarez et al. 1990, de Voogd et al. 1999, Bell \& Barnes 2000), light (Cheshire \& Wilkinson 1991), tidal amplitude (Barnes 1999), and water flow rate (Bell \& Barnes 2000). In addition to environmental parameters, dispersal limitation may be an important factor in explaining the spatial turnover of species (Hooper et al. 2002, Mora et al. 2003, Tuomisto et al. 2003). The relationship, however, between distribution patterns of adults and mode of reproduction has rarely been studied in sponges (Uriz et al. 1998). Sponges have various strategies for reproduction and dispersal. Within the class Demospongiae, for example, the reproductive mode was considered subclass specific, but gradually many exceptions have been found (Hooper \& van Soest 2002). Still, the mode of sexual reproduction appears to apply at ordinal or at least at family level. Thus, based on family membership we may assign viviparity and oviparity. In general, larvae tend to settle in close proximity to the parent sponge, after only a few hours to a day; thus, sponge dispersal is assumed to be limited for most viviparous sponges (Zea 2001). Most oviparous species, however, are expected to exhibit more pronounced dispersal abilities. Although many of the oviparous sponges form their larvae externally, some release zygotes or early embryos (Maldonado \& Uriz 1999).

In addition to comparing oviparous and viviparous species we also compared the 10 most common (present at $>80 \%$ of the surveyed sites) sponge species with the next 11 to 50 most common species (present at $>40 \%$ of the sites). Because of their abundance and distribution, common species should produce a surplus of dispersal propagules. Consequently, we expect distance to be a less important explanatory factor for the most common sponge species than for less common sponge species.

In this study we aim to: (1) Determine whether sponge assemblages are spatially homogeneous and, if not, if the spatial variation in beta diversity (community similarity) is related to distance and/or environment. (2) Determine whether this relationship differs according to sexual reproduction strategy and abundance. Here, we predicted that purely spatial variation would be a stronger predictor of community similarity in viviparous than in oviparous species, and in less common than in common species. (3) Assess the degree to which spatial patterns of sponge diversity can be related to remotely sensed (satellite) and/or locally measured environmental variables. 


\section{MATERIALS AND METHODS}

Location. The research area is located in the Spermonde Archipelago, just off the coast of Makassar, SW Sulawesi, Indonesia. The archipelago is $2800 \mathrm{~km}^{2}$ in size, and consists of 160 fringing reefs, barrier reefs, and patch reefs. Four ecological reef zones were identified, based on cross-shelf distribution of coral species, bathymetry, geography, geomorphology, and distance offshore. The zones differ in biotic and abiotic parameters (van Vuuren 1920, de Klerk 1983, Hoeksema 1990). Offshore sites are relatively oligotrophic, while inshore sites are subjected to outflow from major rivers. The geomorphology of the reefs is determined by the northwest monsoon, between November and April. The eastern sides of the reefs are more sheltered and show more sediment accumulation than the western sides. The northwestern sides of the reefs of Lae-Lae, Bone Baku, Sama lona, Kudingareng Keke, Bone Lola, Barang Lompo, Langkai, and the southeastern sides of the reefs Samalona and Kudingareng Keke were examined (Fig. 1).

These reefs were chosen because they are representative of the prevalent conditions in each zone and have been focal reefs for previous and ongoing studies of other taxa including corals (Moll 1984, Hoeksema 1990, Cleary et al. 2005), sea urchins (de Beer 1990), foraminiferans (Renema 2002), sea cucumbers (Massin 1999), and sea grasses and macroalgae (Verheij 1993).

Sponges. A total of 34 stations were surveyed using SCUBA, from April to July 1997 and April to November 2000. Surveys were made at different depth intervals $(3,6,9,12$, and $15 \mathrm{~m})$ along a $100 \mathrm{~m}$ transect line. Sponge species and their abundance were noted in $1 \mathrm{~m}^{2}$ quadrants laid at each consecutive $1 \mathrm{~m}$ section. Smaller (cryptic, boring, and thinly encrusting $<4 \mathrm{~cm}$ ) specimens were excluded from this study. Species were visually identified in the field, and fragments of unrecognized species were collected for closer examination. Voucher specimens were preserved in $70 \%$ ethyl alcohol and deposited in the sponge collections of the Zoological Museum Amsterdam (ZMA) and the National Museum of Natural History 'Naturalis', Leiden (NNM), the Netherlands. Sponges were, furthermore, classified as viviparous and oviparous based on family membership following Hooper \& van Soest (2002).

Environmental variables and distance. Vertical water visibility and depth were assessed as local environmental variables. Vertical water visibility was measured using a secchi-disc (diameter $30 \mathrm{~cm}$, English et al. 1997) throughout the period of investigation, around noon, near the surveyed sites. The minimal vertical transparency measured at a specific site was used in our analyses. Depth was measured using a computerized depth meter (Suunto). Geographic positions were recorded at each transect with a handheld GPS device (Garmin $12 \mathrm{XL}$ ) and converted to Universal Transverse Mercator values, which were used to generate a matrix of Euclidean distances between pairs of

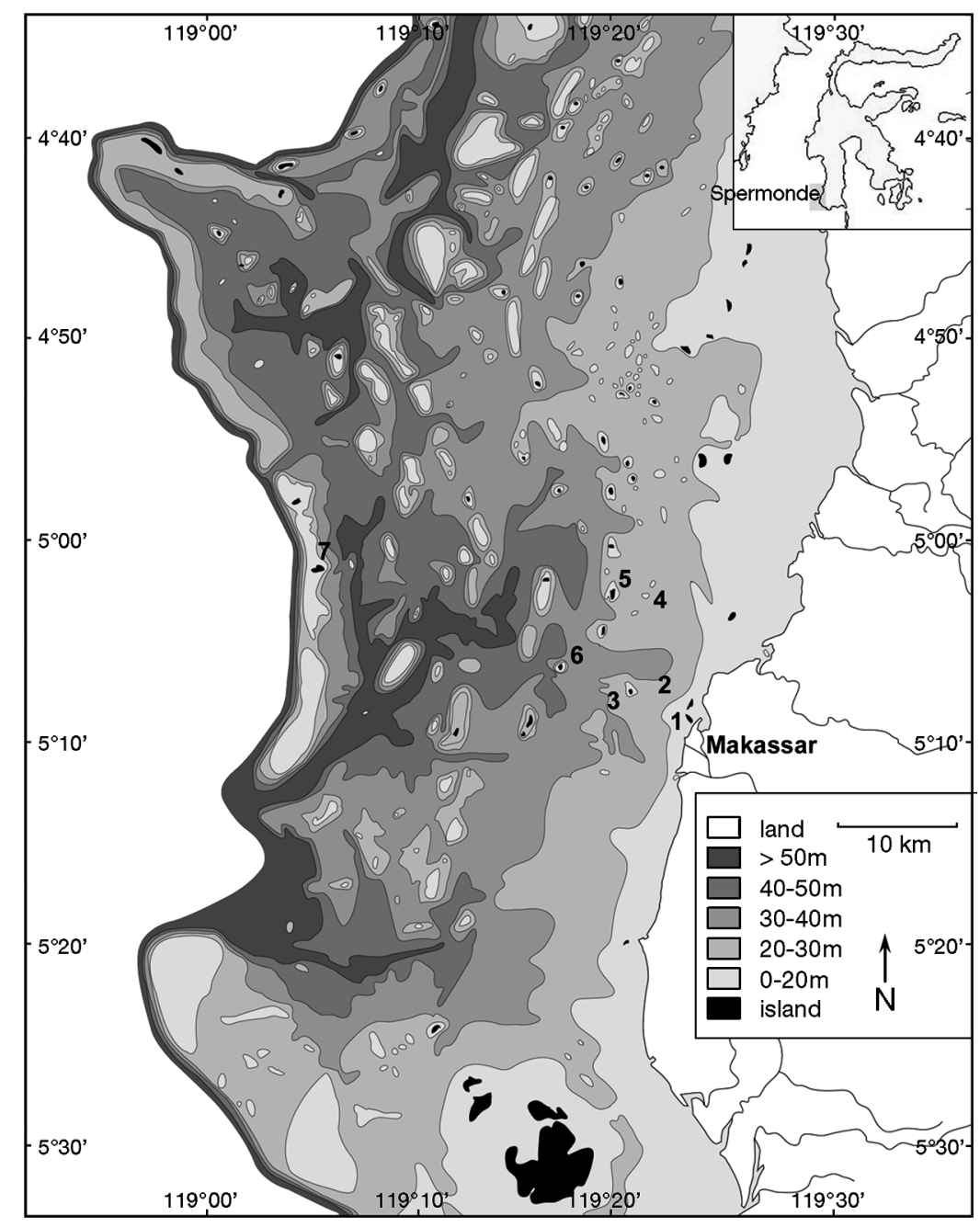

Fig. 1. Map of the Spermonde Archipelago showing the sampled reefs. These included the inhabited islands: (1) Lae Lae, (3) Samalona, (5) Barang Lompo and (7) Langkai, the submerged reefs; (2) Bone Baku, (4) Bone Lola, and the resort island (6) Kudingareng Keke. Inset shows the location of the Spermonde Archipelago in relation to the island of Sulawesi 
sites. In addition to these variables the distance offshore was noted for each sample site.

Remotely sensed environmental variables were calculated with the use of a GIS image based on automatic and supervised classification processes applied to a SPOT-XS satellite image, K-J/Sat: 320-370/3, recorded on 30 August 1995. Verification by field surveys was completed in December 1995. Additional records and corrections were provided by a BCEOM (Le Bureau Central d'Etudes pour les Equipements d'Outre-Mer) consultant in August 1996. The data were collected as part of the Marine Resource \& Education Project (MREP), and is presently managed by BAKOSURTANAL (Badan Koordinasi Survei dan Pemetaan Nasional), Indonesia. The following remotely sensed environmental classes were identified: (1) sedimentary materials (sand, coral rubble, etc. $>60 \%$ of each pixel), (2) coral formations (live coral cover $>60 \%$ of each pixel), (3) sparse coral formations (live coral cover from 40 to $60 \%$ of each pixel), (4) dense hard substratum (>60\% of each pixel), (5) scattered hard substratum (40 to $60 \%$ of each pixel), (6) area of human settlement, (7) island size, and (8) reef size.

Analyses. Total species richness was assessed (using the program Estimates, Colwell 2000) over all transects in order to examine how comprehensive our sampling of the Spermonde Archipelago was. In the 'Results' we present a sample-based rarefaction estimation of cumulative species richness, a Chao2 (see Colwell \& Coddington 1994) nonparametric estimation of cumulative species richness and the cumulative number of uniques and duplicates per transect. The Chao2 estimate gave the least biased estimate of true species richness for small numbers of samples in a study of 8 species richness estimators (Colwell \& Coddington 1994) and has been previously used to assess marine benthic diversity (Ellingsen 2002).

Within PRIMER-5 (Primer-E), $\log _{10}(x+1)$-transformed species abundance data were used to generate a measure of the similarity between plots using the Bray-Curtis similarity index (Bray \& Curtis 1957), often used by ecologists (Legendre \& Gallagher 2001, Ellingsen 2002, Cleary 2003, Cleary \& Genner 2004) and ranked among the best of coefficients tested by Faith et al. (1987). Within PRIMER-5, environmental and spatial data were used to generate a measure of differences in environmental conditions between plots using normalized Euclidean distances. Akaike's information criterion (AIC using Statistica for Windows 6.1, Statsoft) and multiple matrix regression (using PERMUTE! 3.4.9, Casgrain 2001) were used to assess to what extent variation in species richness and community similarity depended upon environmental and/or spatial datasets. The input file for AIC analysis and PERMUTE! consisted of unfolded, upper-triangular matrices, read by rows, in a vertical format. Each column in the input file represented an unfolded, uppertriangular matrix-variable, i.e. a single variable for similarity based on the Bray-Curtis similarity index and a single variable for each of the environmental and distance variables (see Casgrain 2001 for a detailed description of the procedure). Within PERMUTE!, the options selected were forward selection, 999 permutations, and a Bonferroni-corrected p-to-enter of 0.10 . Note that only the variables selected with the AIC procedure were used in the PERMUTE! analyses, in order to test the full model for significance and to assess the relative contribution of each variable to the model after controlling for other variables in the model.

AIC is an information-theoretic alternative to statistical approaches of standard-hypothesis testing, such as multiple regression. AIC (Akaike 1973) uses an entropy maximization principle as a theoretic basis for the selection of models. Akaike (1973) found a simple relationship between Fisher's maximized log-likelihood function and the Kullback-Liebler (K-L) distance (Burnham \& Anderson 1998), thereby providing a simple and effective method for selecting the most-parsimonious model for the analysis of empirical data: $\mathrm{AIC}=$ $-2 \log (L \theta)+2 K$, where $L \theta$ is the maximized log-likelihood, a function of the unknown parameters $\theta$, given the data and the model. $K$ is the number of estimable parameters in the model. AIC is computed for each of the models; the model that minimizes AIC is estimated to be best in the sense of K-L information loss (Burnham \& Anderson 2002). Note that the AIC approach does not generate $\alpha$-significance values, but instead focuses on strength of evidence and generates a measure of uncertainty for each model. In contrast to standard-hypothesis tests, such as stepwise multiple regression, which often yield different results depending on the order in which the models are computed, the AIC yields consistent results and is independent of the order of computation. For a detailed description of the AIC approach see Burnham \& Anderson (1998, 2001, 2002).

In order to assess the relative importance of environmental and spatial factors in structuring community similarity, 3 separate analyses were performed using: (1) all variables, (2) only environmental variables, and (3) only the spatial variable (distance between sample sites). The variance-partitioning technique described by Borcard et al. (1992) was then used to determine the variance explained exclusively by spatial variables (purely spatial component), the variance explained exclusively by environmental variables (purely environmental component) and the variance jointly explained by spatial and environmental variables (spatially structured environmental component). Environmental and spatial variables included: 
(1) $\log _{10}$ transformed area of sedimentary materials, (2) $\log _{10}$ transformed area of coral formations, (3) $\log _{10}$ transformed area of sparse coral formations, (4) $\log _{10}$ transformed area of dense hard substratum, (5) $\log _{10}$ transformed area of scattered hard substratum, (6) $\log _{10}$ transformed area of human settlement, (7) $\log _{10}$ transformed island size, (8) $\log _{10}$ transformed reef size, (9) depth, (10) exposure (sheltered: 0; exposed: 1), (11) $\log _{10}$ transformed water transparency, (12) $\log _{10}$ transformed offshore distance, and (13) $\log _{10}$ transformed distance between sample sites. In addition to testing for an association of the response matrix of community similarity of all sponges, we also tested oviparous sponges, viviparous sponges, the 10 most common (present in greatest number of transects) sponge species, and the next 11 to 50 most common sponge species separately. We furthermore compared pairwise estimates of community similarity using the Sørensen index (Sørensen 1948), which only uses presence-absence data. Since there was a highly significant (all p < 0.001) positive relationship between both indices in all comparisons (range $\mathrm{R}^{2}$ : 0.771 to 0.924 ), we only present the results with the quantitative Bray-Curtis index.

\section{RESULTS}

We identified 15842 individual sponges to a total of 151 species belonging to 68 genera and 37 families. The inventory appeared to be nearly complete because the sample-based rarefaction curve approached an asymptote and the Chao 2 species richness estimator was close to the observed species richness and appeared to stabilize at $169 \pm 10( \pm 1$ standard deviation) species. The curves for uniques (species found only in a single transect) and duplicates (species found only in 2 transects) also clearly declined (Fig. 2).

The greatest overall densities were found for Amphimedon paraviridis (30 ind. $10 \mathrm{~m}^{-2}$ ), Aaptos suberitoides (17.1 ind. $\left.10 \mathrm{~m}^{-2}\right)$, Clathria reinwardti (13.4 ind. $10 \mathrm{~m}^{-2}$ ), Haliclona sp. 'blue' (11.6 ind. $10 \mathrm{~m}^{-2}$ ), Lamellodysidea herbacea (11.5 ind. $10 \mathrm{~m}^{-2}$ ), Hyrtios erectus (8.9 ind. $\left.10 \mathrm{~m}^{-2}\right)$, Stylissa carteri $\left(7\right.$ ind. $\left.10 \mathrm{~m}^{-2}\right)$, Chalinula hooperi (6.6 ind. $10 \mathrm{~m}^{-2}$ ), Clathria cervicornis (5.9 ind. $10 \mathrm{~m}^{-2}$ ), and Petrosia hoeksemai (5.3 ind. $\left.10 \mathrm{~m}^{-2}\right)$.

The number of sponge species found in each of the 34 transects varied between 14 and 77, while total sponge density varied between 1.2 and 12.7 ind. $\mathrm{m}^{-2}$. Only 17 species were common (Kaandorp 1986), i.e. co-occurred in $>22$ different sites (66\% level of sites). We found slightly more viviparous (81) than oviparous (70) species, but the abundance of viviparous species pooled was much higher (11042) than for oviparous

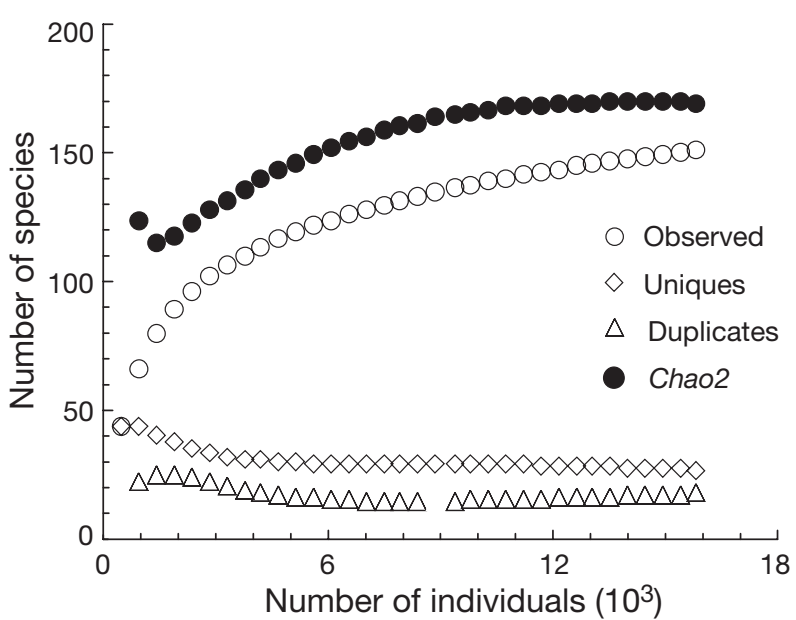

Fig. 2. Sample-based rarefaction curves of observed species richness, the Chao2 richness estimator, uniques and duplicates for all sponge species samples in the Spermonde Archipelago, Indonesia

species (4800). This was mainly due to exceptionally high densities of the species Haliclona sp. 'blue', Lamellodysidea herbacea, Clathria reinwardti, Amphimedon paraviridis, and Hyrtios erectus, which together accounted for $53 \%$ of the total number of individuals. Table 1 lists the 10 most common species in the Spermonde Archipelago.

Species richness was significantly related to depth (partial $b=0.552$, partial $\mathrm{p}<0.001$, partial $\mathrm{R}^{2}=0.305$ ) and human settlement (partial $b=0.129$, partial $\mathrm{p}<0.001$, partial $\mathrm{R}^{2}=0.017$ ), which together explained $32 \%$ of the variation in species richness among transects. Species richness increased with depth (data not shown), with the largest difference between 3 and $6 \mathrm{~m}$ (and appeared to stabilize at $15 \mathrm{~m}$, although there were no surveys that exceeded this depth). Species richness declined with increased human settlement.

Despite a significantly negative univariate association between community similarity and distance between sites (all species: $b=-0.397, \mathrm{p}<0.001, \mathrm{R}^{2}=$ 0.157 ; oviparous species: $b=-0.266, \mathrm{p}<0.001, \mathrm{R}^{2}=$ 0.071 ; viviparous species: $b=-0.435, \mathrm{p}<0.001, \mathrm{R}^{2}=$ 0.189; top 10: $b=-0.259, \mathrm{p}<0.001, \mathrm{R}^{2}=0.067$; top 11 to 50: $b=-0.306, \mathrm{p}<0.001, \mathrm{R}^{2}=0.094$; see Fig. 4), distance did not enter significantly into the multivariate model, indicating that the univariate relationship between distance and community similarity was due to an indirect association with other spatially structured environmental variables (Figs. 3 \& 4, Tables 2 \& 3).

Environmental matrices were significantly associated with the spatial turnover (community similarity) of all species, oviparous, viviparous, most common 10, and most common 11 to 50 species (Table 2). Depth, the area of sparse coral formations, and transparency were significant predictors of spatial variation in all assessed 
Table 1. The 10 most common species and their abundances at different reef sites surveyed. LL: Laelae; BB: Bone Baku; SA: Samalona; BL: Bone Lola; BA: Barang Lompo; KK: Kudingareng Keke; LK: Langkai; E, W: eastern and western sides of reefs

\begin{tabular}{|c|c|c|c|c|c|c|c|c|c|}
\hline \multirow{2}{*}{ Species } & \multirow[b]{2}{*}{ LL } & \multirow[b]{2}{*}{$\mathrm{BB}$} & \multirow[b]{2}{*}{ SA-E } & \multirow[b]{2}{*}{ SA-W } & \multirow{2}{*}{$\begin{array}{l}\text { Location } \\
\text { BL }\end{array}$} & \multirow[b]{2}{*}{ BA } & \multirow[b]{2}{*}{ KK-E } & \multirow[b]{2}{*}{ KK-W } & \multirow[b]{2}{*}{ LK } \\
\hline & & & & & & & & & \\
\hline Amphimedon paraviridis Fromont & 64 & 248 & 52 & 847 & 212 & 22 & 66 & 326 & 58 \\
\hline Callyspongia aff. pseudofibrosa & 24 & 21 & 15 & 37 & 9 & 42 & 12 & 39 & 14 \\
\hline \multicolumn{10}{|l|}{ Desqueyroux-Faúndez } \\
\hline Callyspongia biru de Voogd & 0 & 31 & 125 & 101 & 17 & 17 & 22 & 20 & 40 \\
\hline Chalinula hooperi Bakus \& Nishiyama & 4 & 83 & 12 & 29 & 9 & 5 & 76 & 56 & 165 \\
\hline Clathria reinwardti Vosmaer & 66 & 121 & 236 & 336 & 278 & 193 & 70 & 269 & 24 \\
\hline Haliclona sp. 'blue' & 0 & 33 & 51 & 326 & 70 & 8 & 46 & 60 & 8 \\
\hline Hyrtios erectus Keller & 8 & 39 & 147 & 185 & 138 & 157 & 42 & 86 & 94 \\
\hline Petrosia hoeksemai de Voogd \& van Soest & 2 & 33 & 41 & 153 & 35 & 75 & 13 & 84 & 23 \\
\hline Petrosia nigricans Lindgren & 2 & 15 & 23 & 32 & 38 & 60 & 8 & 76 & 29 \\
\hline Spheciospongia congenera Ridley & 10 & 68 & 15 & 70 & 26 & 12 & 12 & 15 & 4 \\
\hline
\end{tabular}

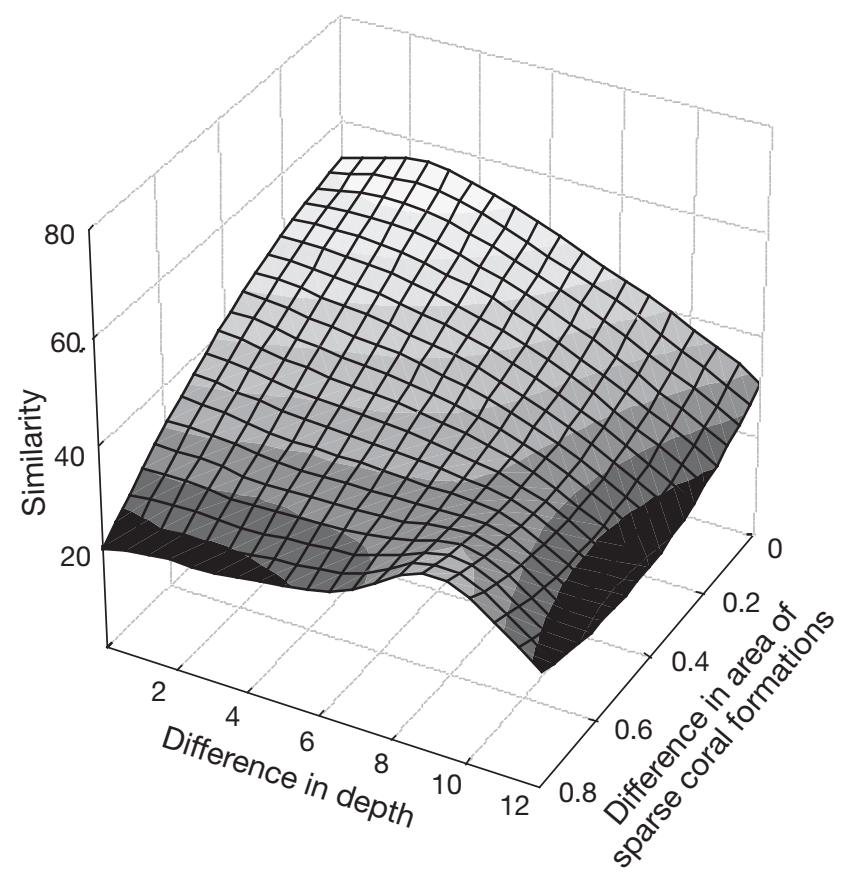

Fig. 3. 3-dimensional surface plot of the community similarity of all sponge species between pairs of sites as a function of the normalized Euclidean difference in sparse coral formations and the Euclidean difference in depth $(\mathrm{m})$ between sites. The fitted plane was obtained with the distance-weighted least squares fitting option in Statistica for Windows 6.1. The shading in the plane indicates variation in the difference in similarity between pairs of transects. Light shading indicates pronounced similarity. The greatest difference in similarity was between transects located at the most different depths and with the most different degree of sparse coral formations

groups (Table 3). The area of coral formations was a significant predictor in all groups except the 10 most common species, and the area of human settlement was a significant predictor in all groups except oviparous species. Additional significant predictors included the area of scattered hard substratum for viviparous species, offshore distance for the 10 most common species, and exposure for the most common 11 to 50 species. Using forward selection, the best predictor variables were the area of sparse coral formations (13 to $23 \%$ of variation explained), followed by depth (9 to $13 \%$ of variation explained). Water transparency explained between 1 and $4 \%$ of the variation in similarity. The area of human settlement explained between 2 and $4 \%$ of the variation in similarity (Table 3 ). The amount of variation explained by the purely spatial component was $0 \%$ in all groups, while the spatially structured environmental component explained between 7 and $18 \%$ of the variation in similarity, and the purely environmental component, between 17 and 29\% (Table 2).

The relationship between similarity and the area of sparse coral formations and depth is shown in Fig. 3, where it can be seen that sites with the greatest overall similarity tended to be located at similar depths and in areas with a similar environment surrounding the sample site. At different depths and in different habitat types, similarity was very low.

\section{DISCUSSION}

The few qualitative studies of sponge distributions at small (Wilkinson \& Cheshire 1988, 1989, Wilkinson \& Evans 1989, Uriz et al. 1992, Carballo et al. 1996, Hooper et al. 1999, de Voogd et al. 1999, Corriero et al. 2000, Zea 2001, Hooper \& Kennedy 2002, Hooper et al. 2002) and large spatial scales (van Soest 1994, Maldonado \& Uriz 1995, Hooper et al. 1999) have shown that sponge assemblages are far from homogeneous, without, however, explicitly relating this to environmental parameters. In the present study we quantitatively showed that sponge assemblages are spatially heterogeneous and that this heterogeneity is strongly related to deterministic (environmental) processes.

In a similar study to ours, Hooper \& Kennedy (2002) found no relationship between similarity and distance 


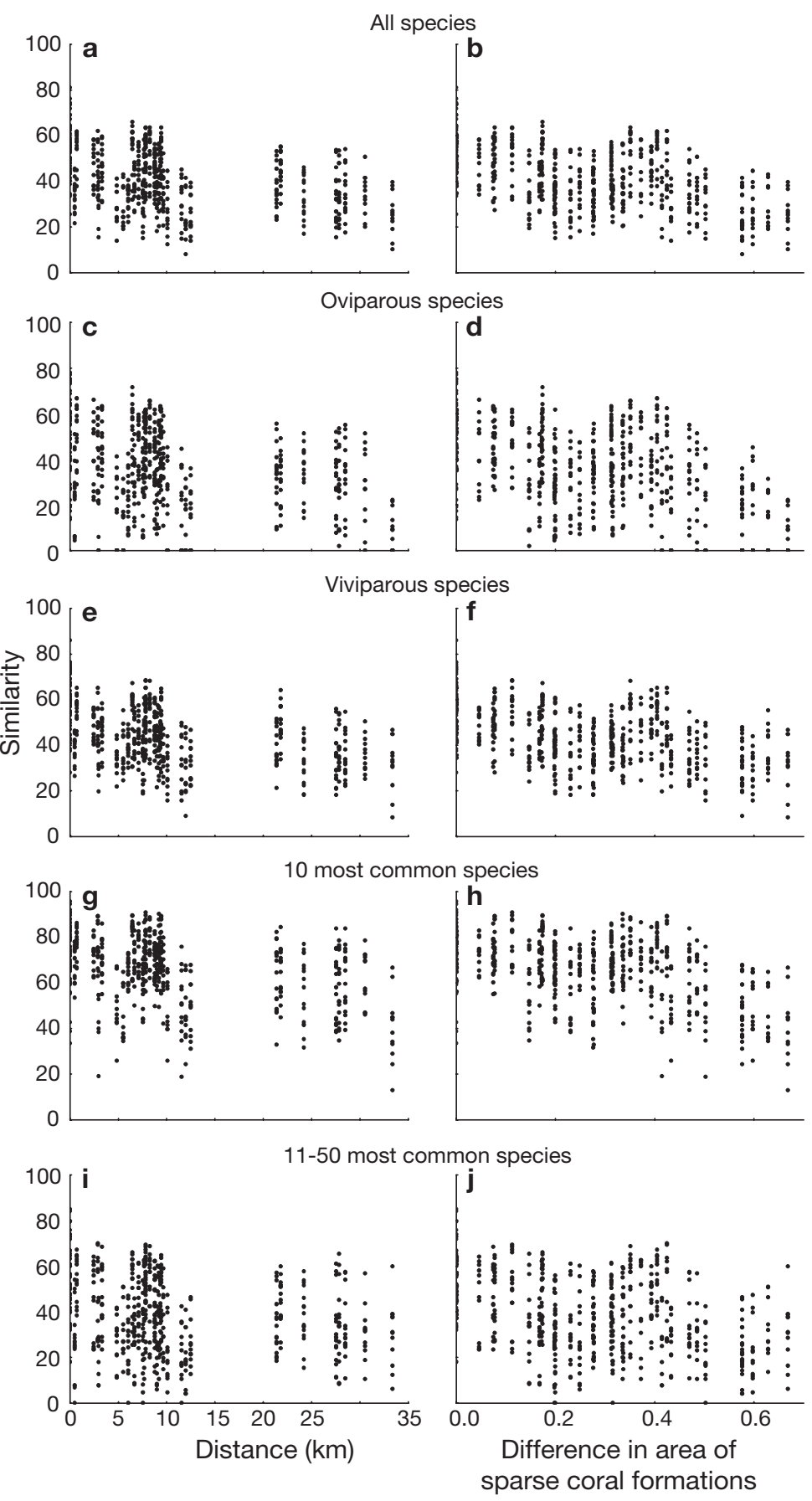

Fig. 4. Relationship between community similarity and distance for: (a) all species, (c) oviparous species, (e) viviparous species, (g) the 10 most common species, and (i) the next 11 to 50 most common species. Relationship between community similarity and difference in area of sparse coral formations for: (b) all species, (d) oviparous species, (f) viviparous species, (h) the 10 most common species, and (i) the next 11 to 50 most common species

between reefs. In an analogous study, Pandolfi (2002) showed that there was a high degree of variance in estimates of community similarity at multiple spatial scales in Caribbean coral communities, indicating that distance per se was not driving community patterns. Zea (1993), on the contrary, found that the distribution of sponge species in the southwestern Caribbean was related to dispersal limitation and noted that greater larval recruitment was observed where adults lived in higher densities.

In contrast to our hypothesis, distance was unimportant in structuring both viviparous and oviparous species assemblages or in structuring less common versus common species assemblages. The lack of a relationship between distance and community similarity suggests that dispersal limitation is unimportant in structuring sponge assemblages within the Spermonde Archipelago. Rather, assemblages of sponges are strongly associated with environmental differences between sites related to habitat heterogeneity, depth, and the degree of human settlement. The environmental effects of human settlement can be extremely complex and may involve a number of confounding factors (Miller \& Hobbs 2002). Two major changes to the local environment, as a result of human settlement, include increased sedimentation and increased eutrophication. Both of these have been shown to affect sponges (Aerts \& van Soest 1997, Bell \& Barnes 2000, Holmes 2000), although in the present study we were not able to disentangle the possible effects that patterns of human settlement have on sponge assemblages. Sedimentation is an important ecological factor for hard bottom biota that can affect their composition, structure, and dynamics. Increased sediment as a result of human perturbation can, furthermore, threaten biodiversity and ecosystem functioning. The response, however, to sedimentation can differ among assemblages, depending on life history and individual developmental stages, in addition to varying over space, time, and different depositional environments. We found, for instance, relatively few species and individuals at sites in shallower water environments and high levels of human settlement. Sponges, in general, do not thrive well in highly disturbed areas, particularly with elevated rates of sedimentation; fine sediments occlude the pores, and pumping rates are drastically reduced (Reiswig 1971, Gerrodette \& Flechsig 1979), although some species such as Paratetilla bacca were virtually restricted to highly perturbed environments. The association, however, with human settlement is not an artifact of hu- 
Table 2. Results of Akaike's information criterion (AIC) and multiple matrix regression analyses. Pure spat: pure spatial component; Spat env: spatially structured environmental component; Pure env: pure environmental component; Total expl: total variation explained by the model

\begin{tabular}{|lccccccc|}
\hline Category & df & AIC & $\begin{array}{c}\text { Pure } \\
\text { spat }\end{array}$ & $\begin{array}{c}\text { Spat } \\
\text { env }\end{array}$ & $\begin{array}{c}\text { Pure } \\
\text { env }\end{array}$ & $\begin{array}{c}\text { Total } \\
\text { expl }\end{array}$ & $p$ \\
\hline Oviparous & 4 & 4625 & 0 & 7 & 26 & 33 & $<0.001$ \\
Viviparous & 6 & 4148 & 0 & 18 & 22 & 40 & $<0.001$ \\
Top 10 & 5 & 4384 & 0 & 7 & 29 & 36 & $<0.001$ \\
Top 11-50 & 6 & 4611 & 0 & 9 & 17 & 27 & $<0.001$ \\
Total & 5 & 4178 & 0 & 16 & 27 & 43 & $<0.001$ \\
\hline
\end{tabular}

Table 3. Results of multivariate nonparametric forward regression analyses using PERMUTE!

\begin{tabular}{|llccc|}
\hline Group & Environmental predictor & Partial $b$ & Partial p & Partial $\mathrm{R}^{2}$ \\
\hline All species & Sparse coral formations & -0.484 & 0.001 & 0.234 \\
& Depth & -0.363 & 0.001 & 0.132 \\
& Coral formations & -0.185 & 0.001 & 0.024 \\
& Human settlement & -0.152 & 0.001 & 0.022 \\
Oviparous species & Water transparency & -0.145 & 0.001 & 0.017 \\
& Sparse coral formations & -0.443 & 0.001 & 0.196 \\
& Depth & -0.318 & 0.001 & 0.101 \\
& Water transparency & -0.163 & 0.001 & 0.021 \\
Viviparous species & Coral formations & -0.110 & 0.005 & 0.009 \\
& Sparse coral formations & -0.457 & 0.001 & 0.208 \\
& Depth & -0.317 & 0.001 & 0.101 \\
& Human settlement & -0.204 & 0.001 & 0.040 \\
& Coral formations & -0.228 & 0.001 & 0.037 \\
& Water transparency & -0.120 & 0.003 & 0.011 \\
& Scattered hard & -0.096 & 0.007 & 0.006 \\
& substratum & & & \\
Most common & Sparse coral formations & -0.443 & 0.001 & 0.196 \\
& Depth & -0.312 & 0.001 & 0.097 \\
& Water transparency & -0.222 & 0.001 & 0.040 \\
& Human settlement & -0.133 & 0.001 & 0.017 \\
Most common & Offshore distance & -0.123 & 0.002 & 0.011 \\
& Sparse coral formations & -0.362 & 0.001 & 0.131 \\
& Depth & -0.305 & 0.001 & 0.093 \\
& Human settlement & -0.126 & 0.001 & 0.015 \\
& Coral formations & -0.131 & 0.005 & 0.012 \\
& Water transparency & -0.106 & 0.013 & 0.009 \\
& Exposure & -0.079 & 0.044 & 0.006 \\
\hline
\end{tabular}

mans inhabiting larger islands or reef areas, since neither of these variables were significant in the multivariate analysis. Our results therefore indicate that patterns of human settlement are already impacting sponge diversity in the Spermonde Archipelago.

Remotely sensed habitat variables, such as the area of sparse coral formations and human settlement, were important predictors of sponge community structure in line with a number of predominantly terrestrial studies on a diverse array of taxa (Rozenzweig 1995, Tilman 1999, Webb 2000, Pearman 2002). In Canada, most of the variation in butterfly species richness was, for example, successfully predicted by remotely sensed data of habitat heterogeneity, with secondary, but sig- nificant, contributions coming from climate and topography (Kerr et al. 2001). Sparse coral formations are characterized by a high structural complexity of the reef substrate in contrast to dense coral formations. Space is a highly limited resource for sessile organisms living on hard substratum (Dayton 1971), and scleractinian corals are the main sponge competitors (Aerts \& van Soest 1997, de Voogd et al. 2004). Consequently, few sponge species are able to settle in dense coral fields, but use the high structural complexity of lower coral cover environments. Also, high structural complexity of the reef substrate is known to promote sponge diversity and abundance (Diaz et al. 1990). Remotely sensed data of marine habitat/substrate types can thus provide important insights into the distribution of sponges. For instance, sites with the greatest overall similarity tended to be located at similar depths and in areas with a similar set of habitats surrounding the sample site. At different depths and in different habitat types, similarity was very low. A large amount of variation in the spatial similarity of various species groups in this study remained unexplained. Similar studies (Borcard et al. 1992, Duivenvoorden et al. 2002, Githaiga-Mwicigi et al. 2002, Magalhaes et al. 2002, Tuomisto et al. 2003) have shown that the amount of unexplained variation in selected taxa (fish, forest trees, birds, mites, bacteria) could be substantial (35 to $77 \%$ ), and may be related to nondeterministic fluctuations, unmeasured environmental variables, or spatial variation acting at a different (i.e. very local or very large) spatial scale or described by a more complex (e.g. polynomial) function. For sponges, local factors related to microenvironment and small-scale variation in substrate have been shown to influence settlement and survival (Hooper \& Kennedy 2002). Competition for space, mediated by allelochemicals (Porter \& Targett 1988), is another important factor determining sponge assemblages at very small spatial scales. Despite the importance of these local factors, however, we still managed to explain $>40 \%$ of the variation in similarity using remotely sensed and locally measured environmental variables, indicating that sponge assemblages respond to their environment at multiple 
spatial scales. It is, furthermore, important to note that the amount of variation explained in this study is well above the mean $(38.4 \pm 13.8 \%)$, but within the range of similar studies that used variance partitioning (Borcard et al. 1992, Duivenvoorden et al. 2002, GithaigaMwicigi et al. 2002, Magalhaes et al. 2002, Tuomisto et al. 2003).

As in the present study, various published studies have attributed spatial variation in community structure to deterministic (environmental) processes. Pure distance, for example, explained very little variation in the community similarity of fish assemblages in Seixe, Portugal (0 out of $58 \%$; Magalhaes et al. 2002), bird assemblages in South Africa (1.7 out of $27 \%$; GithaigaMwicigi et al. 2002), or tree assemblages in Panama (7 out of $41 \%$; Duivenvoorden et al. 2002). Although, in the present study, we tested for differences between viviparous and oviparous sponges, it has to be taken into account that other modes of reproduction may play an important role in sponge recruitment and dispersal. For example, it was concluded that fragmentation was the major mode of propagation for an oviparous verongid sponge in the West Indies when this species had a particular 'rope-shaped' morphology; moreover, the allocation of energy for the production of gametes was largely reduced (Tsurumi \& Reiswig 1997). Thus, sponges with a branch-forming morphology are easily fragmented, and it has been postulated that this mode of asexual reproduction is an important mode of recruitment in sponge populations with this type of morphology (Wulff 1984). Indeed, 3 of the 4 most abundant viviparous sponges Clathria reinwardti, Amphimedon paraviridis and Hyrtios erectus found in the Spermonde Archipelago had a branching or stick-like morphology; thus, the dominance of these species could very well be a result of fragmentation or a maximized recruitment of both interacting modes of reproduction. Although, the Spermonde is prone to physical disturbance originating from the dominant northwest monsoon (Umbgrove 1929, Hutchinson 1945, de Klerk 1983), it is not comparable to the magnitude and frequency of hurricane-driven disturbances in the Caribbean (Hutchinson 1945). Thus, the impact of fragmentation may not be as important in less-disturbed areas, such as in the Indomalayan region. Other modes of dispersal include the ability of some sponge larvae and free-floating buds to mix with plankton (Kelly-Borges \& Bergquist 1988). It has been suggested that detached fragments that contain larvae increase the dispersal capacity of some species (Maldonado \& Uriz 1999). Although there was no purely spatial component, the spatially structured environmental component explained substantially more variation in viviparous than in oviparous sponges and marginally more in the less common than in the most common sponge species. The discontinuous geographic distribution and localized small-scale aggregations of a sponge species in the Mediterranean were related to the very shortdistance dispersal of its crawling larvae, while the geographical ubiquity and small-scale randomness of another species were due to larvae with greater dispersal capabilities (Uriz et al. 1998). The high abundance of certain viviparous species indicates the importance of the various modes of reproduction in the ability to disperse and settle. But Mariani et al. (2000) found a positive correlation between larval and adult abundance of the oviparous sponge Cliona viridis, and suggested that the dispersal ability of the parenchymella larvae is low. This implies that within a sponge community some species can be self-seeding and are important for maintaining the sponge population, whereas other species may act as a source for downstream regions. Clearly sponge dispersal is highly complex. In addition, many species are widespread in the Spermonde Archipelago, a fact probably related to the high connectivity of the individual reefs across the shelf. Few endemics have, furthermore, been recorded that have their whole distribution limited to the Spermonde, in comparison to other studies (Hooper \& Kennedy 2002, Fromont et al. 2005). Barber et al. (2000) remarked that populations of the stomatopod Haptosquilla pulchella were genetically homogenous in the Spermonde Archipelago. They also observed a distinct genetic break in the Indonesian Archipelago over a distance of only $200 \mathrm{~km}$, and concluded that populations within Indonesia might not be as connected as is generally assumed. Thus, dispersal limitation may become more important at larger spatial scales than those assessed in this study. Ayre \& Hughes (2000), for example, remarked that although reefs in the Great Barrier Reef are dependent on the self-seeding of many brooding and spawning corals, gene flow does occur, because of the stepping stone structure of the Great Barrier Reef. Whether a similar structure exists in the Indonesian Archipelago has yet to be investigated for most reef taxa. Many species found in the Spermonde are also known from other Indonesian regions (van Soest 1989, de Voogd \& van Soest 2002). In the growing awareness that biodiversity has to be preserved, the processes that regulate diversity need to be better understood. Mora et al. (2003) stressed the importance of speciation and dispersal abilities of species in the Indomalayan center of biodiversity for assembling communities in the Indian and Pacific Oceans. Unfortunately, our understanding with respect to the generality of this biodiversity, distribution pattern, and responses to environmental factors is still limited (Hooper \& Kennedy 2002).

The present study shows that environmental processes, particularly those related to sparse coral forma- 
tions, depth, and human settlement, explain a large amount of the variation in sponge similarity within the Spermonde Archipelago. These results should facilitate our understanding of marine biodiversity hotspots such as Indonesia. Similar studies in proximate areas such as the marine park of Taka Bone Rata (SE Sulawesi), Bunaken National Park (NE Sulawesi), and the Berau Area (NE Kalimantan) are suggested for a better understanding of sponge distributional patterns.

Acknowledgements. This research was funded by the Netherlands Foundation for the Advancement of Tropical research (WOTRO Grant W84-474), the Dutch Royal Academy of Science (KNAW), and the STIR-network. The Indonesian Institute of Sciences (LIPI) supported the logistics within Indonesia. All field assistants are thanked for their support. Three anonymous reviewers are thanked for improving an earlier version of this manuscript.

\section{LITERATURE CITED}

Aerts LAM, van Soest RWM (1997) Quantification of sponge/coral interactions in a physically stressed reefcommunity, NE Colombia. Mar Ecol Prog Ser 148:125-134

Akaike $H$ (1973) Information theory as an extension of the maximum likelihood principle. In: Pertrov $\mathrm{BN}$, Csaki F (eds) Proceedings of the 2nd international symposium on information theory. Akademiai Kiado, Budapest, p $267-281$

Alvarez B, Diaz MC, Laughlin RA (1990) The sponge fauna on a fringing coral reef in Venezuela. I. Composition, distribution, and abundance. In: Rützler K (ed) Proceedings of the 3rd international sponge conference. Smithsonian Institution Press, Washington, DC, p 358-366

Amir I (1992) A comparison of sponge fauna of exposed and sheltered reef flats in eastern Indonesia. Mar Res Indones 28:1-12

Ayre DJ, Hughes TP (2000) Genotypic diversity and gene flow in brooding and spawning corals along the Great Barrier Reef, Australia. Evolution 54:1590-1605

Barber PH, Palumbi SR, Erdman MV, Moosa MK (2000) A marine Wallace's Line? Nature 406:692-693

Barnes DKA (1999) High diversity of tropical intertidal-zone sponges in temperature, salinity and current extremes. Afr J Ecol 371:424-434

Bell JJ, Barnes DKA (2000) A sponge diversity centre within a marine island. Hydrobiologia 440:55-64

Borcard D, Legendre P, Drapeau P (1992) Partialling out the spatial component of ecological variation. Ecology 73: 1045-1055

Bray JR, Curtis JT (1957) An ordination of the upland forest communities of southern Wisconsin. Ecol Monogr 27: 325-349

Brickle NW (2002) Habitat use, predicted distribution and conservation of green peafowl (Pavo muticus) in Dak Lak province, Vietnam. Biol Conserv 105:189-197

Briggs JC (1992) The marine East Indies: Centre of origin? Global Ecol Biogeogr Lett 2:149-156

Briggs JC (1999) Coincident biogeographic patterns: IndoWest Pacific Ocean. Evolution 53:326-335

Briggs JC (2000) Centrifugal speciation and centres of origin. J Biogeogr 27:1183-1188

Burnham KP, Anderson DR (1998) Model selection and inference: a practical information-theoretic approach Springer-Verlag, New York

Burnham KP, Anderson DR (2001) Kullback-Leibler information as a basis for strong inference in ecological studies. Wildl Res 28:111-119

Burnham KP, Anderson DR (2002) Model selection and multimodel inference: a practical information-theoretic approach, 2nd edn. Springer-Verlag, New York

Carballo JL, Naranjo SA, García-Gómez JC (1996) Use of marine sponges as stress indicators in marine ecosystems at Algeciras Bay (southern Iberian Peninsula). Mar Ecol Prog Ser 135:109-122

Casgrain P (2001) PERMUTE! 3.4.9. Freeware available at www.fas.umontreal.ca./biol/casgrain/en/labo/permute/ index.html

Cheshire AC, Wilkinson CR (1991) Modelling the photosynthetic production by sponges on Davies Reef, Great Barrier Reef. Mar Biol 109:13-18

Cleary DFR (2003) An examination of scale of assessment, logging and ENSO-induced fires on butterfly diversity in Borneo. Oecologia 135:313-321

Cleary DFR, Genner MJ (2004) Changes in rainforest butterfly diversity following major ENSO-induced fires in Borneo. Global Ecol Biogeogr 13:129-140

Cleary DFR, Becking LE, de Voogd NJ, Renema W, de Beer M, van Soest RWM, Hoeksema BW (2005) Variation in the diversity and composition of benthic taxa as a function of distance offshore, depth and exposure in the Spermonde Archipelago, Indonesia. Estuar Coast Shelf Sci 65:557-570

Colwell RK (2000) EstimateS version 6.0b1: Statistical estimation of species richness and shared species from samples. Available at http://viceroy.eeb.uconn.edu/EstimateS

Colwell RK, Coddington JA (1994) Estimating terrestrial biodiversity through extrapolation. Phil Trans R Soc Lond B 345:101-118

Corriero G, Liaci LS, Ruggiero D, Pansini M (2000) The sponge community of a semi-submerged Mediterranean Cave. PSZN I: Mar Ecol 21(1):85-96

Dayton PK (1971) Competition, disturbance and community organization: the provision and subsequent utilization of space in a rocky intertidal community. Mar Ecol Prog Ser 60:291-297

de Beer M (1990) Distribution patterns of regular sea urchins (Echinodermata: Echinoidea) across the Spermonde shelf, SW Sulawesi (Indonesia). In: de Ridder C, Dubois P, Lahaye M, Jangoux M (eds) Echinoderm research. Proceedings of the 2nd European conference on echinoderms. Balkema, Rotterdam, p 165-169

de Klerk (1983) Zeespiegels, riffen en kustvlakten in Zuidwest Sulawesi, Indonesie, een morphogenetischbodemkundige studie. PhD thesis, University of Utrecht, The Netherlands

de Voogd NJ, van Soest RWM (2002) Indonesian sponges of the genus Petrosia Vosmaer (Demospongiae: Haplosclerida). Zool Meded Leiden 76:193-209

de Voogd NJ, van Soest RWM, Hoeksema BW (1999) Crossshelf distribution of southwest Sulawesi reef sponges. Mem Qld Mus 44:147-154

de Voogd NJ, van Soest RWM, Noor A, Hoeksema BW (2002) An assessment of sponge mariculture in the Spermonde Archipelago, Indonesia. Boll Mus Ist Biol Univ Genova 66/67:205

de Voogd NJ, Becking LE, Noor A, Hoeksema BW, van Soest RWM (2004) Sponge interactions with spatial competitors in the Spermonde Archipelago. Boll Mus Ist Biol Univ Genova 68:253-261

Diaz MC, Alvarez B, Laughlin RA (1990) The sponge fauna on 
a fringing coral reef in Venezuela. II. Community structure. In: Rützler K (ed) New perspectives in sponge biology. Smithsonian Institution Press, Washington, DC, p 367-373

Duivenvoorden JF, Svenning JC, Wright SJ (2002) Betadiversity in tropical forests. Science 295:636-637

Ellingsen KE (2002) Soft-sediment benthic biodiversity on the continental shelf in relation to environmental variability. Mar Ecol Prog Ser 232:15-27

English S, Wilkinson C, Baker V (1997) Survey manual for tropical marine resources. AIMS, Townsville

Faith DP, Minchin PR, Belbin L (1987) Compositional dissimilarity as a robust measure of ecological distance. Vegetatio 69:57-68

Fransen CHJM (2002) Taxonomy, phylogeny, historical biogeography, and historical ecology of the genus Pontonia Latreille (Crustacea: Decapoda: Caridae: Palaemonidae) $\mathrm{PhD}$ thesis, Leiden University

Fromont J, Vanderklift MA, Kendrick GA (2006) Marine sponges of the Dampier Archipelago, Western Australia: patterns of species distributions, abundance and diversity. Biodiversity Conserv (in press)

Gerrodette T, Flechsig AO (1979) Sediment-induced reduction in the pumping rate of the tropical sponge Verongia lacunose. Mar Biol 55:103-110

Githaiga-Mwicigi JMW, Fairbanks DHK, Midgley G (2002) Hierarchical processes define spatial patterns of avian assemblages restricted and endemic to the arid Karoo, South Africa. J Biogeogr 29:1067-1087

Henderson FM, Xia ZG (1997) SAR applications in human settlement detection, population estimation and urban land use pattern analysis: a status report. IEEE Trans Geosci Remote Sens 35:79-85

Hoeksema BW (1990) Systematics and ecology of mushroom corals (Scleractina, Fungiidae). PhD thesis, Leiden University

Hoeksema BW, Putra KS (2003) The reef fauna of Bali in the centre of marine diversity. Proc 9th Int Coral Reef Symp 1: 173-178

Holmes KE (2000) Effects of eutrophication on bioeroding sponge communities with the description of new West Indian sponges, Cliona spp. (Porifera: Hadromerida: Clionidae). Invertebr Biol 119:125-138

Hooper JNA, Kennedy JA (2002) Small-scale patterns of sponge biodiversity (Porifera) on Sunshine Coast reefs, eastern Australia. Invertebr Syst 16:637-653

Hooper JNA, van Soest RWM (2002) Systema Porifera. A guide to the classification of sponges. Kluwer Academic/ Plenum Publishers, New York

Hooper JNA, Kennedy JA, List-Armitage SE, Cook SD, Quinn $\mathrm{R}$ (1999) Biodiversity, species composition and distribution of marine sponges in northeast Australia. Mem Qld Mus $44: 263-274$

Hooper JNA, Kennedy JA, van Soest RWM (2000) Annotated checklist of sponges (Porifera) of the South China Sea region. Raff Bull Zool Suppl 8:125-207

Hooper JNA, Kennedy JA, Quinn RJ (2002) Biodiversity 'hotspots', patterns of richness and endemism, and taxonomic affinities of tropical Australian sponges (Porifera). Biodivers Conserv 11:851-885

Hutchinson DR (1945) Coral reefs and cays of the Makassar Straits. HQ Allied Air Forces SW Pacific Area Intelligence Mem 50:1-30

Kaandorp JA (1986) Rocky substrate communities of the infralittoral fringe of the Boulonnais coast, NW France: a quantitative survey. Mar Biol 92:255-265

Kauferstein S, Mebs D (1999) Living in a risky environment. Coral Reefs 18:106
Kelly-Borges M, Bergquist PR (1988) Success in a shallow reef environment: sponge recruitment by fragmentation through predation. Proc 6th Int Coral Reef Symp 2: $757-762$

Kerr JT, Southwood TRE, Cihlar J (2001) Remotely sensed habitat diversity predicts butterfly species richness and community similarity in Canada. Proc Natl Acad Sci USA 98:11365-11370

Legendre P, Gallagher ED (2001) Ecologically meaningful transformations for ordination of species data. Oecologia 129:271-280

Magalhaes MF, Batalha DC, Collares-Pereira MJ (2002) Gradients in stream fish assemblages across a Mediterranean landscape: contributions of environmental factors and spatial structure. Freshw Biol 47:1015-1031

Maldonado M, Uriz MJ (1995) Biotic affinities in a transitional zone between the Atlantic and the Mediterranean: a biogeographical approach based on sponges. J Biogeogr 22: 89-110

Maldonado M, Uriz MJ (1999) Sexual propagation by sponge fragments. Nature 398:476

Mariani S, Uriz MJ, Turon X (2000) Larval bloom of the oviparous sponge Cliona viridis: coupling of larval abundance and adult distribution. Mar Biol 137:783-790

Massin C (1999) Reef-dwelling Holothuroidea (Echinodermata) of the Spermonde Archipelago (South-West Sulawesi, Indonesia). Zool Verh 329:1-144

Miller JR, Hobbs RJ (2002) Conservation where people live and work. Conserv Biol 16:330-337

Moll H (1984) Zonation and diversity of Scleractinia on the reefs off SW Sulawesi, Indonesia. PhD thesis, Leiden University

Mora C, Chittaro PM, Sale PF, Kritzer JP, Ludsin SA (2003) Patterns and processes in reef fish diversity. Nature 421: 933-936

Munro MHG, Blunt JW, Lake RJ, Litaudan M, Battershill CN, Page MJ (1994) From seabed to sickbed: What are the prospects? In: van Soest RWM, van Kempen Th MG, Braekman JC (eds) Sponges in time and space. Balkema, Rotterdam, p 473-484

Munro MHG, Blunt JW, Dumdei EJ, Hickford SJH, Lill RE, Li S, Battershill CN, Duckworth AR (1999) The discovery and development of marine compounds with pharmaceutical potential. J Biotechnol 70:15-25

Pandolfi JM (2002) Coral community dynamics at multiple scale. Coral Reefs 21:13-23

Pearman PB (2002) The scale of community structure: habitat variation and avian guilds in tropical forest understory. Ecol Monogr 72:19-39

Pet-Soede C (2000) Options for co-management of Indonesian coastal fishery. PhD thesis, University of Wageningen

Plotkin JB, Muller-Landau HC (2002) Sampling the species composition of a landscape. Ecology 83:3344-3356

Porter JW, Targett NM (1988) Allelochemical interactions between sponges and corals. Biol Bull (Woods Hole) 175: 230-239

Reiswig HM (1971) Particle feeding in natural populations of 3 marine demosponges. Biol Bull (Woods Hole) 141: 568-591

Renema W (2002) Larger foraminifera as marine environmental indicators. Scripps Geol 124:1-260

Rozenzweig ML (1995) Species diversity in space and time. Cambridge University Press

Santini F, Winterbottom R (2002) Historical biogeography of Indo-western Pacific coral reef biota: Is the Indonesian region a centre of origin? J Biogeogr 29:189-205

Sørensen T (1948) A method of establishing groups of equal 
amplitude in plant sociology based on similarity of species content. Biol Skr 5:1-34

Spalding MD, Ravilious C, Green EP (2001) World atlas of coral reefs. University of California Press, Berkeley, Los Angeles, CA

Spencer M, Schwartz, SS, Blaustein L (2002) Are there finescale patterns in community similarity among temporary freshwater pools? Global Ecol Biogeogr 11:71-78

Tilman D (1999) The ecological consequences of changes in biodiversity: a search for general principles. Ecology 80: 1455-1474

Tsurumi M, Reiswig HM (1997) Sexual vs. asexual reproduction in oviparous rope-form sponge Aplysina cauliformis (Sponges; Verongida). Invertebr Reprod Dev 32:1-9

Tuomisto H, Ruokolainen K, Yli-Halla M (2003) Dispersal, environment, and floristic variation of western Amazonian forests. Science 299:241-244

Turner W, Spector S, Gardiner N, Fladeland M, Sterling E, Steininger M (2003) Remote sensing for biodiversity and conservation. Trends Ecol Evol 18:306-314

Umbgrove JHF (1929) The influence of the monsoons on the geomorphology of coral islands. In: Proceedings of the 4th Pacific science congress. Baks \& Klits, Batavia-Bandoeng, Java, $\mathrm{p} 49-54$

Uriz MJ, Rosell D, Martín D (1992) The sponge population of the Cabrera Archipelago (Balearic Islands): characteristics, distribution, and abundance of the most representative species. PSZN I: Mar Ecol 13(2):101-117

Uriz MJ, Maldonado M, Turon X, Martí R (1998) How do reproductive output, larval behaviour, and recruitment contribute to adult spatial patterns in Mediterranean encrusting sponges? Mar Ecol Prog Ser 167:137-148

van Soest RWM (1989) The Indonesian sponge fauna: a status report. Neth J Sea Res 23:223-230

van Soest RWM (1990) Shallow-water reef sponges of eastern Indonesia. In: Rützler K (ed) New perspectives in sponge biology. Smithsonian Institution Press, Washington, DC, p 302-308

Editorial responsibility: Otto Kinne (Editor-in-Chief), Oldendorf/Luhe, Germany van Soest RWM (1994) Demosponge distribution patterns. In: van Soest RWM, van Kempen ThMG, Braekman JC (eds) Sponges in time and space. Balkema, Rotterdam, p 213-224

van Vuuren (1920) Barrière-riffen en atollen in den Ned. Indischen Archipel. In: Proc. 1ste Ned.-Indisch Natuurwetensch. Baks \& Klits, Batavia-Bandoeng, Java, p 186-198

Verheij E (1993) Marine plants on the reefs of the Spermonde Archipelago, SW Sulawesi, Indonesia: aspects of taxonomy, floristics and ecology. PhD thesis, Leiden University

Wallace CC, Paulay G, Hoeksema BW, Bellwood DR, Hutchings PA, Barber PH, Erdmann M, Wolstenholme J (2003) Nature and origins of unique high diversity reef faunas in the Bay of Tomini, Central Sulawesi: the ultimate 'Centre of diversity'. Proc 9th Int Coral Symp 1: 185-192

Webb CO (2000) Exploring the phylogenetic structure of ecological communities: an example for rain forest trees. Am Nat 156:145-155

Wilkinson CR, Cheshire AC (1988) Cross-shelf variations in coral reef structure and function-influences of land and ocean. Proc 6th Int Coral Reef Symp 1:227-233

Wilkinson CR, Cheshire AC (1989) Patterns in the distribution of sponge populations across the central Great Barrier Reef. Coral Reefs 8:127-134

Wilkinson CR, Evans EA (1989) Sponge distribution across Davies Reef, Great Barrier Reef, relative to location, depth and water movement. Coral Reefs 8:1-7

Wulff JL (1984) Sponge-mediated coral reef growth and rejuvenation. Coral Reefs 3:157-163

Zea S (1993) Recruitment of demosponges (Porifera, Demospongiae) in rocky and coral reef habitats of Santa Marta, Columbian Caribbean. PSZN I: Mar Ecol 14:1-21

Zea S (2001) Patterns of sponge (Porifera, Demospongiae) distribution in remote, oceanic reef complexes of the Southwestern Caribbean. Rev Acad Col Cien Exac Físicas Nat 25:579-592

Submitted: July 15, 2004; Accepted: September 1, 2005 Proofs received from author(s): January 31, 2006 